Our Nature 2013, 11(1): 31-35

\title{
Buchwaldoboletus lignicola (Basidiomycetes), an Inedible Wild Mushroom New to Nepal
}

\author{
Hari Prasad Aryal $^{{ }^{*}}$ and Usha Budathoki ${ }^{2}$ \\ ${ }^{1}$ Paklihawa Campus, Bhairahawa, Institute of Agriculture and Animal science, T.U., Nepal \\ ${ }^{2}$ Central Department of Botany, Kirtipur, Kathmandu, T.U., Nepal \\ *E-mail: hahariprasadaryal06@gmail.com
}

Received: 10.11.2012, Accepted: 05.06.2013

\begin{abstract}
The survey of wild mushrooms in tropical to temperate belts of Nepal during the rainy season was conducted in 2012. The Buchwaldoboletus lignicola (Kallenb.) Pilat, which is being reported and redescribed for the first time from Nepal. The habitat of the fungus was subtropical deciduous hill forest between 1030 to $1360 \mathrm{~m} \mathrm{msl}$. The dried specimen is deposited in the Tribhuvan University Central Herbarium (TUCH), Kirtipur Kathmandu, Nepal.
\end{abstract}

Key words: Taxonomy, Basidiomycetes, Macrofungus, Buchwaldoboletus lignicola

\section{Introduction}

Buchwaldoboletus lignicola (Kallenb.) Pilat is principally a tropical genus which is nonmycorrhizal, saprophytic and lignicolous that grows on woods, in association with the brown-rot Phaeolus spp.

The genus Buchwaldoboletus is represented by 12 species world over (Santana and Both, 2011). This mushroom was first described by Franz Joseph Kallenbach in 1929 as Boletus lignicola. This species was formally given its current name by Pilat (1969). He first placed it in the genus Pulveroboletus before denoting the new genus Buchwaldoboletus. Pilat (1965) transferred Boletus lignicola to Pulveroboletus in 1969; he proposed the genus Buchwaldoboletus to accommodate Boletus lignicola (type species) and $B$. hemichrysus. He characterized the two members of the genus by their lignicolous habit, lack of veil, decurrent and arcuate hymenophore, the stipe with yellow mycelium, the bluing yellow flesh and the absence of hyphal clamps. It is only found where the fungus Phaeolus spp. grows, and it is parasitic on that species. Its remarkable aspect is that, the trees favored by the bolete are also the same that are infested by the polypore. The wood brokendown by the polypore might provide a favorable substrate for the bolete (Szczepka and Sokol, 1984). They are found in coniferous as well as deciduous forests.

\section{Study area}

The study area lies in Lumbini zone, Palpa district, Masyam VDC ward No.9 in the western Mahabharat range of Nepal (Fig. 1). The area lies in subtropical zone embracing different types of vegetation and soil composition. The forest is dominated by members of the Combretaceae, Diptero- 
carpaceae, Fagaceae and Myrtaceae families. This study area covered 22.75 ha of forested land (DFO, 2008) and lies between $27.51120^{\circ}-27.51698^{\circ} \mathrm{N}$ latitude and $83.07790^{\circ}-83.07392^{\circ} \mathrm{E}$ longitudes. The altitudinal range varies between 1030 and $1360 \mathrm{~m}$ asl. The average annual rainfall is $1391 \mathrm{~mm}$ (GoN, 2010).

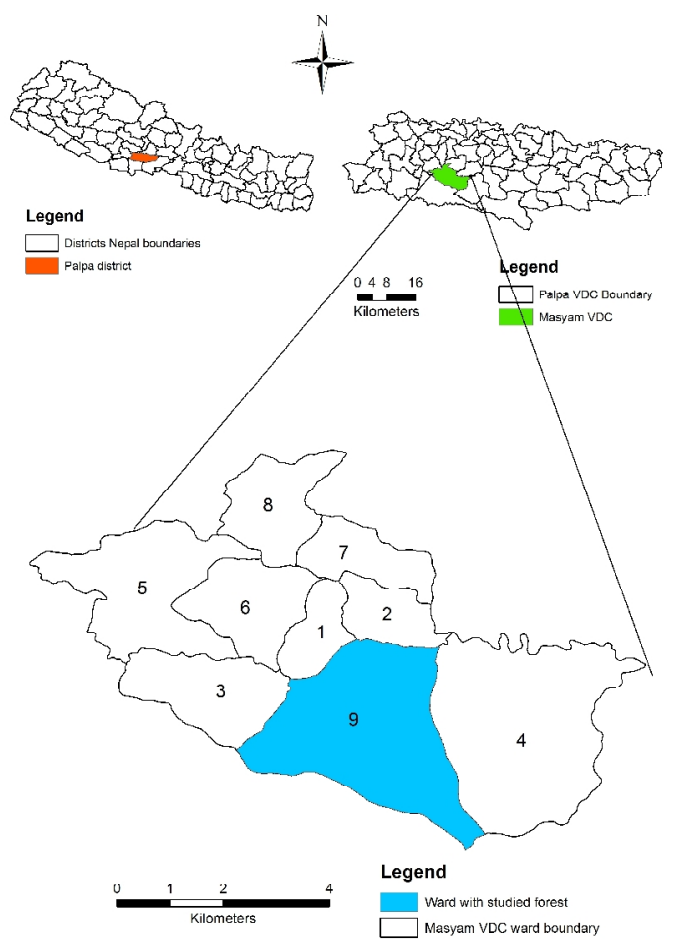

Figure 1. Map of study site.

\section{Materials and methods}

The specimens were collected from $15^{\text {th }}$ July to $1^{\text {st }}$ August 2012, photographed in their natural habitat and morphological characters were noted. Spore prints were also taken (Pl. 1). The habitat parameters viz., altitude (by altimeter), vegetation composition, soil type, soil $\mathrm{pH}$ (by digital $\mathrm{pH}$ meter), soil moisture (by nail $\mathrm{pH}$ meter), humidity, temperatures and time (by means of thermo-Hygrometer) were recorded. The wax paper bag was brought to central Department of botany, Tribhuvan University, for further microscopic examination.

The specimens were studied based on habitat, macroscopic and microscopic characteristics. Slide was prepared and measurement of spores was taken. Chemical reactions (Tulloss, 1994) were performed regarding the sample study by placing a small piece of material in $5 \% \mathrm{KOH}$ solution, followed to the $\mathrm{NH}_{3} \mathrm{OH}, \mathrm{FeSO} 4$ (Solution and Crystal) and its colour compared with the commercial colour chart leaf-let. For microscopic study the specimens were sectioned by using a sharp razor blade. The cyanophility was observed in cotton blue mounted in lactophenol reagent. The photographs were taken with a SONY DSC S980 Camera, macroscopic and microscopic characters were studied under the hand lens and the compound microscope, Olympus No. 575096, Tokyo (Japan) respectively and latitude and longitude were taken by means of GPS compass.

The voucher specimens were identified with the help of relevant literature such as Singer (1986), Dick and Snell (1965), Cotter (1987), Both (1993), Watling (2008) and Website (biodiversity library.org, Boletes in Pacific Northwest, Index fungorum, Jstor.org, Mycobank.org, Scirus.com, tropicos.org. The voucher specimen is deposited in the TUCH.

\section{Results and discussion}

Buchwaldoboletus lignicola (Kallenb.) Pilat, 1969, Friesia 9: 217-218.

Basionym: Boletus lignicola Kallenbach, 1929, in Die Pilze Mitteleuropas, Band 1. Die 
Rohrlinge (Boletaceae), 57p.

Synonyms: Boletus sulfurous Fries forma silvestris Kallenbach, 1924, Annales Mycologici 22: 410414; Xerocomus (Singer, 1942); Gyrodon (Heinemann, 1951); Pulveroboletus (Pilat, 1965); Pulveroboletus (Dick and Snell, 1965).

Local name: Lati Dhyabre Chyau

Taxonomic position (Kuo, 2003):

Basidiomycota

Basidiomycetes

Agaricomycetidae

Boletales

Boletaceae (Pl. 1)

Identifying Fungi with stipe and cap with characters: pores beneath, tubes detachable, stipe central, typically terrestrial. Pileus and stipe tomentose, reddish brown, dry, context yellow, blueing above the tube.

Description of species:

Basidiocarp: Boletoid, characterized by the yellow-brown to reddish brown, found in wood rather than ground.

Pileus: Dry,7-10 cm, at first hemispherical then expanding to convex, ochraceous or light brown, velvety, distinctly dry even in wet weather, unchanging when bruised, cap margin rolled inwards, easily peeled off. Pileus and stipe, covered with soft appressed tomentum which is easily detersible, attached to the flesh by a thin gelatinous layer, so that the tomentum can move back and forth, below Pelicle, yellow with granular chocolate brown in colour.

Corntext: Yellow, bluing above tubes, decurrent and arcuate pores.

Tube: 1-3 $\times$ 3-12 $\mathrm{mm}$, at first bright yellow, then olivaceous yellow, unchanging when exposed to air detersible, decurrent, pores bright yellow, unchanging when bruised yellow to golden, bruising greenishblue.

Stipe: $3-8 \times 1-2.5 \mathrm{~cm}$, equal, reddish violet, pelicle not separable, below it dark in colour, basal area sulphuryellow, ending in a bright-yellow mycelium. Cylindrical or spindleshaped, usually tapering towards the base, mostly concolorous with the cap, but sometimes yellow in the upper parts.

Flesh: Whitish or yellowish, unchanging or blueing slightly above the tubes.

Odour: Pleasant in young conditions, and become very disagreeable in older ones.

Taste: Not distinctive.

Hyphae: Absent of clamp connection.

Spore print: Rust 0569.

Spores: Smooth, cylindric-fusoid, 6-9 × 3$4 \mu \mathrm{m}$.

Cystidia: Large and conspicuous, ventricose, subclavate, $29-80 \times$ 4-9 $\mu \mathrm{m}$.

Habit: Usually solitary, rarely two to four specimens fused together, no truly caespitose, lignicolous habit. 
Hari Prasad Aryal and Usha Budathoki / Our Nature (2013) 11(1): 31-35

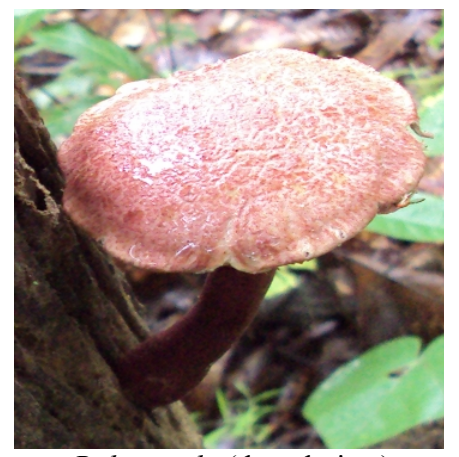

B. lignicola (dorsal view)

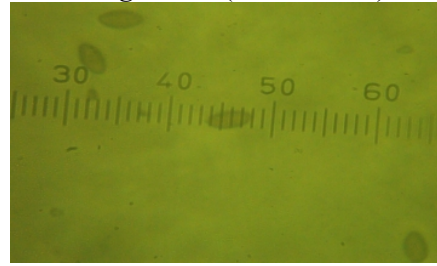

Spores $(1 \operatorname{div}=1.66 \mu \mathrm{m})$

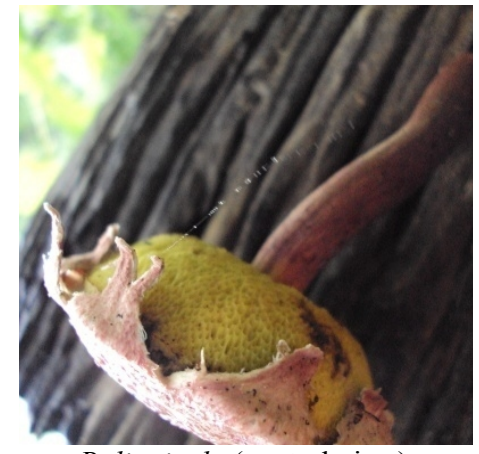

B. lignicola (ventral view)

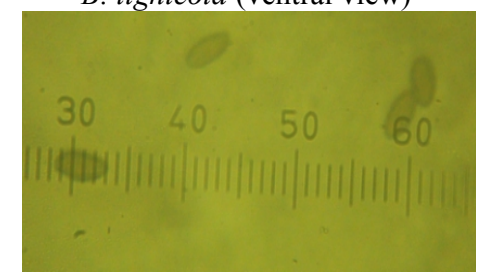

Spore $(1 \mathrm{div}=1.66 \mu \mathrm{m})$

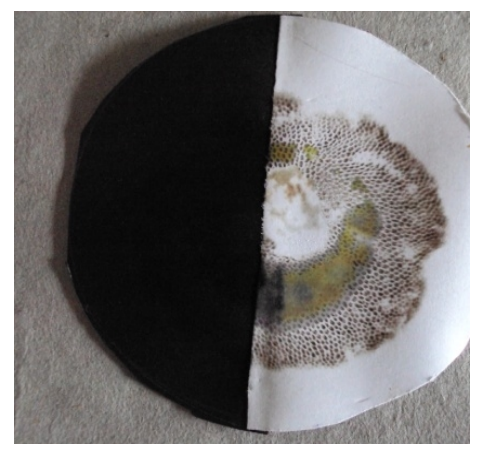

Spore print

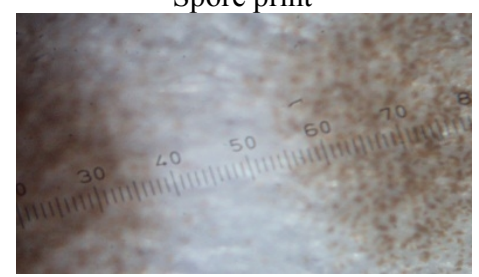

Lamellae difference $(1 \mathrm{div}=11.66$ $\mu \mathrm{m})$

Plate 1. Morphology of B. lignicola.

Habitat: At the base of or on top stumps of conifers, Picea smithiana, Pinus roxburghii, by the polypore: strobes and other pines, rarely with deciduous trees (Prunus spp.). Often together with the polypore Phaeolus spp.

Season: July-August.

Ecology: Parasite on the fungus Phaeolus spp.

Chemical reaction with

$\mathrm{NH}_{3} \mathrm{OH}$ : Negative on all the parts.

$\mathrm{KOH}$ : Yellows grey on cap surface.

$\mathrm{FeSo}_{4}$ Stipe outer: negative, inner: solution: coffee 0468, Cap: negative, Gills: Magnolia 0387.

$\mathrm{FeSo}_{4}$ crystal: Stipe outer: negative, inner: Sandalwood 0485, Cap: negative, Gills: Limon 7778.

Specimen Nepal, Palpa, Masyam VDC, examined: ward No. 9, $1350 \mathrm{~m}$, long. $83.52119^{\circ} \mathrm{E}$, lat. $27.78258^{\circ} \mathrm{N}$, Aspect: $104^{\circ} \mathrm{S} / \mathrm{E}, \quad$ Slop: $40^{\circ} \mathrm{N} / \mathrm{E}$, Temp.: $21.9-24.6^{\circ} \mathrm{C}$, Humidity: $\quad 77-87 \%$, Soil moisture: $5.9 \%$, Time: 9:15 am; Coll No. 1008329. Growing on log (Pinus roxburghii), Sal dominant forest. Aryal, H.P., Date: 28.08.2012. No previously reported from the country, hence new to Nepal. This species is common in subtropical to temperate region of Nepal.

Distribution: Europe, North America, Africa, Nepal. 


\section{Hari Prasad Aryal and Usha Budathoki / Our Nature (2013) 11(1): 31-35}

The reported mushroom is widely spread throughout the country from tropical to temperate belts. The study sites are phytogeographically a diverse terrain and rich in mushroom diversity and offers immense scope for investigation and studies. The B. lignicola is new record for Nepal.

\section{Acknowledgements}

The authors would lie to acknowledge Nepal Academy of Science and Technology for providing research grant. Thanks are due to Central Department of Botany, Tribhuvan University for laboratory facilities. The authors are also grateful to the Institute of Agriculture and Animal Science for granting study leave to one of them (Mr. Hari Prasad Aryal). Sincere thanks are extended to local people of the study area for providing information.

\section{References}

Both, E.E. 1993. The Boletes of North America. A compendium, Buffalo Museum of Science Buffalo, New York. 436p.

Cotter, H.V.T. 1987. The systematic and ecology of boletes with special reference to the genus Suillus and its ectomycorrhizal relationship in Nepal. Faculty of the Virginia Polytechnic Institute and State University, Blacksburge, Virginia, U.S.A. 175p. (Ph.D. Thesis)

DFO. 2008. Yearly monitoring and evaluation, analysis report of community forest. District Forest Office, Palpa. Fiscal year 2065/066 B.S.

Dick, E.A. and W.H. Snell 1965. Notes on Boletes-
XV. Mycologia 57(3): 448-458.

GoN. 2010. Climatological and agrometeorological records of Nepal. Government of Nepal. Ministry of Environment, Science and Technology. Department of Hydrology and Meteorology, Kathmandu, Nepal.

Heinemann, P. 1951. Champignons recoltes au Congo Belge par Madame Goossens-Fontana I Boletineae. Gyrodon. Bulletin $d u$ Jardin botanique de I'Etat a Bruxelles 21: 223-346.

Kallenbach, F. 1924. Boletus sulphureus Fries forma silvestris. Annales Mycologici 22: 410-414.

Kallenbach, F. 1929. Boletus lignicola. In: Die Rohrilinge (Boletaceae), Ed. D.P. Mitteleuropas. Band 1: 56-60.

Kuo, M. 2003. Mushroom taxonomy: The big picture. Retrieved from http://www.mushroomexpert.com/taxonomy.html

Pilat, A. 1965. Hrib drevozijny- Pulveroboletus lignicola (Kallenb.) na Sumave. Ceska Mykologie 19(3): 180-181.

Pilat, A. 1969. Buchwaldoboletus, genus novum Boletacearum. Friesia 9: 217-218.

Santana, B.O. and E.E. Both 2011. A preliminary study of the genus Buchwaldoboletus. Bull. Buff. Soc. Nat. Sci. 40: 1-14.

Singer, R. 1942. Das system der Agaricales- II Annales Mycologici 40: 1-132.

Singer, R. 1986. The Agaricales in modern taxonomy $4^{\text {th }}$ ed., Bishen Singh and Mahendra Pal Singh, Dehradun, India.

Szczepka, M.Z. and S. Sokol 1984. Buchwaldoboletus lignicola (Kallenb.) Pilat and Phaeolus schweini (Fr.) Pat.-das Problem ihres gemeinsamen Auftretens. Zeitschrift fur Mykologie 50(1): 95-99.

Tulloss, R.E. 1994. Seminario sobre Amanita Supporting materials for a seminar on Amanita, Univ. Autón. Tlaxcala. 127p.

Watling, R. 2008. A manual and source book on the boletes and their allies. Synopsis Fungorum 24. Fungiflora, Oslo. 248p. 